
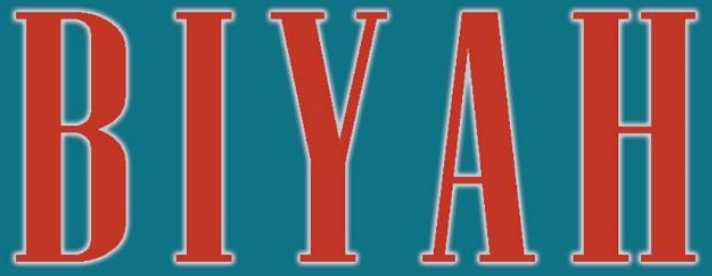

INTEGRATION OF ISLAMIC VALUES IN ENGLISH LEARNING AT MADRASAH IBTIDAIYAH TEACHER TRAINING PROGRAM (PGMI) UIN NORTH SUMATERA

THE IMPORTANCE OF THE EFFECTIVENESS LEADERSHIP CONCEPT IN BUILDING ISLAMIC EDUCATION

LEADERSHIP POLICY IN DEVELOPING OF ISLAMIC SCHOOL EDUCATION CURRICULUM AT DARUL ARAFAH BOARDING SCHOOL IN DELI SERDANG REGENCY

CONTRIBUTION OF MAHMUD YUNUS ISLAMIC EDUCATION LEARNING METHOD IN AL-TARBIYAH WA-ALTA'LIM BOOK

ISLAMIC EDUCATION PERSPECTIVE IMAM AL-GHAZALI AND IT'S RELEVANCE WITH EDUCATION IN INDONESIA

THE EFFECT OF WORK MOTIVATION AND WORK STRESS ON TEACHER PERFORMANCE

HUMANISTIC CHARACTER EDUCATION CURRICULUM MODEL IN SDIT NURUL FIKRI ACEH BESAR

STUDY OF EXPOSITION PARAGRAPH DEVELOPMENT INTARBIYAH AND TEACHER TRAINING FACULTY STUDENTS

MULTICULTURAL EDUCATION IN MADRASAH DINIYAH AS PREVENTION OF RELIGIOUS CONSERVATISM

THE IMPROVEMENT OF STUDENT'S MATHEMATICAL COMMUNICATION ABILITY BY USING COOPERATIVE LEARNING: COURSE REVIEW HORAY 


\section{JURNAL TARBIYAH}

Published biannually, January-June and July-December editions, containing scientific articles of tarbiyah, Islamic education, conceptual, research results, study of books and biographies of figures

\section{Chancellor}

Dean Fakultas Ilmu Tarbiyah dan Keguruan UIN Sumatera Utara Medan

\section{Editor in Chief}

Mesiono

\section{Editors}

Junaidi Arsyad

Sakholid Nasution

Eka Susanti

Sholihatul Hamidah Daulay

Maryati Salmiah

\section{Reviewers}

Ayang Utriza Yakin, Universitas Islam Negeri Syarif Hidayatullah Jakarta, Indonesia Rahmah Fithriani, Universitas Islam Negeri Sumatera Utara Medan, Indonesia Irwan Padli Nasution, Universitas Islam Negeri Sumatera Utara Medan, Indonesia Firman, Universitas Negeri Padang, Indonesia

Nafan Tarihoran, IAIN Sultan Maulana Hasanuddin Banten, Indonesia Jamal, Universitas Negeri Bengkulu, Indonesia

Khairil Ansyari, Universitas Negeri Medan, Indonesia

Ibnu Hajar, Universitas Negeri Medan, Indonesia

Saiful Anwar, Institut Agama Islam Negeri Raden Intan Lampung, Indonesia

\section{Graphic Designer}

Suendri

\section{Secretariat}

Reflina

Nurlaili

Sahlan 


\title{
INTEGRATION OF ISLAMIC VALUES IN ENGLISH LEARNING AT MADRASAH IBTIDAIYAH TEACHER TRAINING PROGRAM (PGMI) UIN NORTH SUMATERA
}

\author{
Riris Nur Kholidah Rambe', Salminawati² \\ 1,2 Universitas Islam Negeri Sumatera Utara, Medan, Indonesia \\ Email: ${ }^{1}$ ririsnurkholidah@gmail.com, ${ }^{2}$ salminawati@gmail.com
}

\section{DOI : 10.30829/tar.v26i1.410 \\ Date submitted : 14 March 2019 \\ Published : 30 June 2019}

\begin{abstract}
Abstrak: Penelitian ini bertujuan untuk mengetahui: (1) Bagaimana Materi Ajar Bahasa Inggris; (2) Bagaimana Konsep Nilai-Nilai Islam dalam Materi ajar Bahasa Inggris; dan (3) Bagaimana mengintegrasikan nilai- nilai Islam dalam materi ajar Bahasa Inggris di Prodi Pendidikan Guru Madrasah Ibtidaiyah (PGMI) UINSumatera Utara.Penelitian ini merupakan penelitian kepustakaan (Library Research) yang merupakan salah satu jenis penelitian kualitatif. Karakteristik yang mendasar dalam penelitian ini adalah bahwa data yang diteliti merupakan karya pustaka tertulis berupa dokumen dalam bentuk buku atau literatur. Penelitian ini menganalisa materi Bahasa Inggris yang diajarkan di Prodi PGMI, kemudian diintegrasikan dengan nilai Islam pada beberapa materi di mata kuliah Bahasa Inggris.Temuan penelitian ini sebagai berikut: (1) Materi ajar Bahasa Inggris yang digunakan di prodi pendidikan guru madrasah Ibtidaiyah membahas lima kemampuan dasar yaitu: reading, vocabulary, writing, grammar, dan speaking. (2) Konsep nilai-nilai Islam yang diintergrasikan kedalam pembelajaran Bahasa Inggris sudah tertuang didalam silabus yang terintegrasi. (3) Dalam mengintegrasikan nilai-nilai Islam dalam perkuliahan Bahasa Inggris, ada beberapa aspek yang perlu digabungkan, antara lain: (1) pendekatan; (2) kurikulum; (3) materi ajar; dan (4) metode perkuliahan .
\end{abstract}

Kata Kunci: Integrasi, Nilai - Nilai Islam, Pembelajaran Bahasa Inggris.

\begin{abstract}
This study aimed to find out: (1) HowEnglish Language Teaching Materials were; (2) How the Concept of Islamic Values in English Language Teaching Materials was; and (3) How to integrate Islamic values in English teaching materials at the Madrasah Ibtidaiyah Teacher Training program (PGMI) at UIN North Sumatra. This research was library research which is one type of qualitative research. The fundamental characteristic in this study was that the data studied was written literature in the form of documents namely books or literature. This study analyzed the English material taught in PGMI Study Program, then integrated with Islamic values on some material in English courses. The research findings were 1) English teaching materials which were used in PGMI discussed five basic abilities, namely reading, vocabulary, writing, grammar, and speaking; 2) the concept of Islamic values which wasintegrated into English learning was contained in an integrated syllabus;3) in integrating Islamic values in English language lectures, there were several aspects that needed to be combined, including approach, curriculum, teaching material, and lecture methods.
\end{abstract}

Keywords: Integration, Islamic values, English learning 
مستخلص: يستهدف البحث لمعرفة: 1). كيف مادة التعليم للغة الإنجليزية، 2). كيف مفهوم القيم الإسلامياة في مادة تعليم اللغة الإنجليزية، 3). كيف يتم تكامل القيم الإسلامية في مادة تعليم اللغة الإنجليزية بقسم تربية المدرسين للمدرسة الإبتدائية بالجامعة الإسلامية الحكومية سومطرة الشمالية. هذا البحث هو البحث المكتبي وهو من نوع البحث الكيفي. وأما خصية البحث فهي البيانات المبحوثة هي المراجع المكتبية المكتوبة المدونة. حلل البحث مادة تعليم اللغة الإنجليزية بقسم تربية المدرسين للمدرسـة الإبتدائية وتكاملها بالقيم الإسلامية في بعض موضوعاتها. نتائح البحث هي: 1). مادة تعليم اللغة الإنجليزية المستخدمة في قسم تربية المدرسين للمدرسـة الإبتدائية تشمل على خمس قدرة أسـاسية وهي القرائة والمفردات والكتابة، والتراكيب والمحادثة. 2) القيم الإسلامية المتكاملة في مادة تعليم اللغة الإنجليزية كانت متضهمنة في الخطة الدراسية اليومية المتكاملة. 3). هناك العناصر التي يضمنها في تكامل القيم الإسلامية بمادة اللغة الإنجليزية وهي المدخل والمنهج والمادة وطريقة التعليم. الكلمات المفتحاية: التكامل، القيم الإسلامية وتعليم اللغة الإنجليزية.

\section{Introduction}

Islamic education is an Islamic education system in order to realize the idealized figure of a Muslim, namely an expert in thought and remembrance (ūlul al-Bāb). Thus, philosophically the theories of education that are built must be derived from Islamic teachings as a reference for developing knowledge and values that will be internalized in educational practice. The source of Islamic education consists of six types, namely the Qur'an, as-Sunnah, the words of Prophet Muhammad's friends, the benefit of the people, traditions or customs of the people and the thoughts of experts on the scope of Islamic thought. The six sources of Islamic education are hierarchically seated. That is, the reference to Islamic education must begin with the Qur'an and then proceed to the next sources. (Hasan Langgulung, 1987: 43).

Today's higher education is generally still reductionist in nature, which is too small and narrow in its perspectives on seeing and analyzing a problem. We can also easily see the practice of lectures in higher education in Indonesia. The concept of linearity, for example, is still often found in Higher education in Indonesia. Requirements for 
continuing study from undergraduate to postgraduate and doctoral level, even the requirement to recruit prospective teaching staff in higher education is still guided by linearity. Linearity is limited to the management of scientific bureaucracy in the management of the study programs, goods are still understandable; but scientific linearity if understood strictly and rigidly will bound the workings, ways of thinking, creativity and innovation of the lecturers and students. (M. Amin Abdullah, 2018, 208209).

Efforts to integrate science and religion all this time seem to be a difficult thing to do. The real science is the result of observation, experimentation and work ratios on one side separated from religion (Islam). Knowledge integration cannot be achieved simply by gathering two scientific associations that have different theoretical bases (secular and religious). Instead, this integration must be pursued to the epistemological level. Combining two different, secular and religious sciences, in an educational institution like what has happened so far without being followed by epistemological construction is an effort that will not produce an integration, but it will only be like gathering in the same space two entities that are going on their own (Mulyadhi Kartanegara, 2004, 208-209).

Kuntowijoyo (2006: 49) argues that there are paradigmatic differences between secular sciences and integralistic sciences. Secular sciences are products together with all humans, while integralistic sciences are products with human believers. We assume that the secular sciences are currently in crisis, experiencing stagnation, and full of bias here and there (philosophical, religious, ethnic politics, etc.).

English language learning is one of the sciences taught in universities, especially the Madrasah Ibtidaiyah Teacher Training Program (PGMI). In the lecture process, students are taught how to apply English in their daily lives, both in listening, speaking, reading, and writing. In its delivery, students must pay attention to the values and cultural elements that apply to the language so that they can apply it contextually. Please note that English is a language that applies in several countries, such as the United Kingdom, the United States, Australia, and others. In these countries, the values and cultural elements they apply are very different from the values and culture in Indonesia, even some of their values and culture are contrary to the values and culture adopted by the Indonesian population, the majority of whom are Muslims. So there is a concern that "more English, less Islam", the more knowledge about English, the less Islamic values in a student. This has become the basis of reflection for many parties, especially among educators, about how English language education can apply Islamic values so that there is no term dichotomy between religious science and general science. 
Integration of Islamic values in lectures in PGMI is an effort to combine two scientific associations that have different theoretical bases (general and religious) by analyzing subject matter found in general and religious subjects, then designed into a comprehensive guidebook so that it becomes an integral whole.

This study will describe how to integrate Islamic values in learning English in PGMI at UIN North Sumatera.

\section{Review Of Literature}

\section{Concept of Integrated Learning}

In Menuk (2003), integration has the meaning of unification to become a whole or rounded entity. The term integration itself comes from English which is integrated. In the book The Contemprorary English Indonesian Dictionary (Peter Salim), the term integrates (vt) integrated, integrating, integrates translated into combining, integrating, integrating. While integrated (adj) is translated into being able to get along with people from various tribes on the same basis; integrated.

Integration is an approach that involves several subjects to provide meaningful learning experiences for students (Yudaamijaya, 2014). Meaningful means that in integrated learning the students will understand the concepts that they learn through direct experience and relate them to other concepts that they understand. Effective learning integration will help create broad opportunities for students to see and build interrelated concepts.

In this study, the integration referred to integrate general sciences or general subjects which are included in the scope of subjects taught by PGMI lecturers by linking them with Islamic values so that they become a unified whole.Imam Suprayogo (2012) developed the concept of scientific integration by illustrating it as a tree of science.

In line with the explanation above, UIN Sunan Kalijaga Yogyakarta describes its scientific paradigm with the term "Theoantropocentric-Integralistic Scientific Spider Web". He illustrates that the visibility or horizon of science is integralistic so broad (not Myopic) as well as skilled in living the traditional and modern sectors because he mastered one of the basic sciences and skills that can sustain life in the current information-globalization era.

In addition, it is illustrated the figure of a religious person who is skilled in handling and analyzing issues that touch humanitarian and religious problems in the modern and post-modern era with the mastery of various new approaches given by natural sciences, social science and contemporary humanities. Above all, in every step taken, it is always 
accompanied by a foundation of objective and robust religious moral ethics because the existence of the Qur'an is interpreted in a new (hermeneutical) manner, it is merely the foundation of the human view of life(welthanchung)in religion which unites in one breath scientific and religious. All of that is enshrined for human welfare together regardless of ethnic, religious, racial or class background. (Amin Abdullah, 106-107).

In solving educational problems if we only use monodiscipline, we will be faced with various weaknesses that arise where we only understand those disciplines without understanding other disciplines which can be used to complement the disciplines that we understand. In the academic world today is characterized by the existence of separate disciplines. Integration is therefore a key word needed to improve understanding. The approach by utilizing a single or monodisciplinary discipline can no longer provide an optimal contribution to the efforts needed to overcome global problems and become increasingly complicated.

Basic competency is the competence of each subject for each class derived from core competencies. Basic competency is content or competence which consists of attitudes, knowledge, and skills that are based on core competencies that must be mastered by the students. These competencies are developed by taking into account student's characteristics, initial abilities, and characteristics of a subject.

From those explanations, 2013 Curriculum Design places spiritual attitudes and social attitudes in the first and second place in the learning process. Explicitly seen here is the great desire for the realization of the application of the curriculum in improving national morals through the implementation of education. But it is very unfortunate, the application in lectures is not the main focus or in other words indirect teaching when teaching the cognitive realm. This seems to be trapped in the previous curriculum design which prioritizes the cognitive domain. Although its position is placed in number one and two, in practice it is only a complement, because it is not clearly explained the content that will be delivered to students. This will result in non-uniformity in its application in the field.

\section{Characteristics of Integrated Learning}

From some of the opinions of the experts mentioned above, it can be concluded that the characteristics of integrated learning include:

a. Student centered

b. The separation amongthe subject matters is not very clear. 
One of the most characteristic of this lecture is that there is no clear boundary among subjects as a result of the view of this lecture that combines various kinds of subjects in a particular theme. Integrated lectures focus attention on observing an event from several subjects at once. Separation between subject matters is not highlighted so as to enable students to understand a lecture phenomenon from all sides. The focus of the lecture is directed at discussing the themes that are most closely related to students' lives.

c. Presenting concepts from various subject matter in a learning process.

This lecture is flexible and can be adjusted according to the development of the student, the situation, and conditions during the lecture so that it is more effective to be used. Integrated learning examines a phenomenon of various aspects that form a kind of inter-schematic relationship among the students, the interrelationships among other concepts will add meaning to the concepts that are fully learned and students are expected to be able to apply the results obtained when learning to solve real problems in his life.

\section{d. Flexible}

Integrated learning is flexible, because lecturers can associate teaching materials from one teaching material with other subjects, even with students' lives and the environment in which schools and students are located.

e. The results of lectures can develop according to the interests and needs of students. Students are given the opportunity to optimize their potential according to their interests and needs.

\section{Development of models of the Science and Religion Integration}

In order to realize the integration of science and religion, especially Islamic values into subjects in the Islamic Elementary School, there are various types of models that can be applied including:

a. Science Integration

To achieve the level of epistemological integrity, integration must be sought in several aspects, namely: ontological integration, integration of scientific classification, and methodological integration.

1. Ontological integration is identifying thesubject matter, which will be the object of research in the contained sciences.

2. Integration of scientific classification. Muslim philosophers such as al-Farabi built scientific classifications based on three main groupings of knowledge, namely: (a). Metaphysics, which deals with forms and their properties, which classifies types of forms and those which are related to beings that are not objects. 
(b). Mathematics, consisting of: arithmetic, geometry, astronomy, music, optics, the science of style and mechanical devices. (c). The natural sciences, which investigate natural objects and accidents in them, are divided into mineralogy, botany and zoology.

3. Methodological integration. The scientific method developed by Muslim thinkers significantly differs from the scientific method developed by western thinkers who only use one type of scientific method, namely observation. While Muslim thinkers use three kinds of methods according to the level or hierarchy of their objects, namely the observation method (tajrîbi), logical or demonstrative methods (burhâni), and intuitive methods (irfâni) which each boast of the senses, reason, and heart. (Mulyadhi Kartanegara: 209-219).

Integration of science and religion can be carried out in taking the core philosophy of fundamental Islamic sciences as a paradigm of future science. The philosophical core is the existence of an epistemological, desiological, cosmological and theological hierarchy that corresponds to the integralism hierarchy: matter, energy, information, values and sources. This process of integration can be regarded as the Islamization of science as part of the process of Islamization of future civilizations. Thus, if the IAIN has been expanded to become a State Islamic University, it can become a node in the revival of Islamic civilization in the future, accepting science back as a lost student to be developed towards a more constructive, productive and harmonious Islamic competition with the public universities to become a center of excellence. Only then can we hope that the Islamic civilization of the world will rise again.

Bagir, et al. offering the concept of integrating value education and dividing it into four levels of implementation, namely: conceptual, institutional, operational and architectural levels. In the conceptual level, the integration of value education can be realized through the formulation of the vision, mission, goals and school programs (school strategic plans). As for institutionally, integration can be realized through the formation of an institution's culture that reflects a blend of values and learning. While at the operational level, curriculum and extracurricular design must be mixed in such a way that the fundamental values of religion and science are integrated coherently. While architecturally, integration can be realized through the formation of a science and technology-based physical environment, such as complete religious facilities, laboratory facilities. Adequate, as well as a library that provides complete religious and general science books. (Armahedi Mahzar in Zainal Abidin Bagir et al: 110-111). 
According to Suwarna (2007: 33-37) in evaluating the process of integrating value education, we can use $5 \mathrm{P}$ valuation techniques (papers and pencils, portfolio, project, product, and performance). This ${ }_{5} \mathrm{P}$ assessment is really directed at the context of value education in family, school, and society. The assessment of the paper and paper is a written assessment. The written test should also question the values contained in it. The portfolio is a collection of tasks, achievements, self-existence or daily portraits of learners. The form of portfolio assignments is tiered and some are descriptive. The project is a structured task. As a structured task, the project is mandatory.

This is usually related to the phenomenon of value education that must be studied, analyzed, and reported by the learner. Meanwhile, the intended product is the work of the learner for his creativity. Learners can make creative works on their own initiative, for example, producing short stories, caricatures or making poems that contain a character. While what is meant by performance is self-appearance. Actually, the essence of value education is the realization of noble mind and character in speaking, acting, feeling, working, short of the word copyright, taste, and intention in everyday life.

There are several models proposed by the people for the reintegration of science and religion. The models can be classified by calculating the number of basic concepts that are the main components of the model.

The first model is the monadic model. This model is popular among fundamentalists, religious and secular. Religious circles say that religion is a whole that contains all branches of culture. Secular circles regard religion as a branch of culture. Religious fundamentalists are regarded as the only truth and science is only one branch of culture, whereas in secular fundamentalism, culture is the expression of human beings in creating a life based on science as the only truth. Thus, a totalistic monadic model like this cannot happen coexistence between religion and science, because both of them affirm each other or take sides with one of them. It seems that this totalistic approach is difficult to use as a landscape of the integration of science and religion in educational institutions from kindergarten to high school.

The second model, the dyadic model. There are several variations in this dyadic model. The first says that science and religion are two equal truths. Science talks about scientific facts while religion speaks of divine values.

The second variant of the dyadic model can be expressed in the image of a circle divided by a curved line into an equal area, as in the symbol of the Tao in the Chinese tradition. This model is a complementary dyadic model. The third variant can be illustrated in a diagram with two equally large intersecting circles. If the two circles reflect 
science and religion, there will be a similarity. That is what the material for dialogue between science and religion is.

The third model is the triadic model as a correction of the independent dyadic model. In the triadic model, there is a third element that bridges science and religion. The bridge is philosophy. This model is put forward by slogans theosophists. "Truth is the similarity between science, philosophy, and religion".

\section{Integration of Islamic Values in Learning English}

In integrating Islamic values in English lectures, there are several aspects that need to be synergized, including:

1. Approach

To integrate Islamic values into learning English, there are several approaches that can be taken, including:

\section{a. Curricular Approach}

The Curricular Approach is an approach in which educational institutions provide the color of "Islam in their education". This is by putting aside the knowledge of religion with general science. For example, at the State Islamic University; accompanying public faculties and religious faculties.

b. Context-functional approach

The context-functional approach is an attempt to answer the question so that all the fields of study presented always wearing the views of Islam. But the main stumbling block to realizing this idea lies in the lecturer. Not many lecturers can master general and religious disciplines in a comprehensive manner.

As an educator, we are faced with the secular nature applied by western educators to approaches in all branches of science. Meanwhile, we believe that Islamic values can be applied through activities and interactions between educators and students such as applying basic Islamic values when giving greetings, leaving places, conducting student discussions, reading prayers when starting and closing lessons, etc. where all these activities can also be accompanied by practice in English. For example, usually in greeting, the lecturer said "Good Morning / Afternoon / Evening. How are you today? " We can replace it by saying "Assalamu'alaikum, peace be upon him, and good morning / afternoon / evening, everyone. How are you today? "

Then, if you want to start and end the lesson, students must pray first. Besides that, in class management, we can also emphasize Islamic integrity in gender issues. From an early age, students should be introduced to sit separately between men and women both 
in working on daily learning assignments and in discussion interactions. By introducing these rules, it is expected that students can understand that Islam has clear rules in terms of socializing. Starting from simple things, the application of Islamic values in the context of everyday Muslim life should be better appreciated.

\section{Education Curriculum}

The basic foundation of Islamic curriculum preparation must include the following principles: a) Contain basic unitary values for the equality of Islamic values at all times and places; b) contains the value of unity of interest in developing the mission of Islamic teachings; c) contains material that contains spiritual, intellectual and physical development.

The limits of the characteristics of an Islamic curriculum are as follows: 1) The system and curriculum development are in harmony with human nature; 2) directed to achieve the final target for students, namely sincere and obedient worship to Allah; 3) Paying attention to the periodization of student development, typology, nature, and gender; 4) should maintain all the real needs of people's life while still relying on the soul and ideal of Islamic ideals; 5) does not cause conflict in the general sense; 6) can be realized according to the situation and conditions; 7) Flexible so that it can be adapted to various local conditions and situations by keeping in mind the individual civilization factors that concern students' talents, interests and abilities; 8) being effective, conveying and arousing educational value tools that produce positive behavior; 9) paying attention to the development of students (religious feelings and language growth); 10) Paying attention to Islamic religious behavior.

Regarding the principle that became the basic link of the curriculum, al-Syaibani provided the following description; the first, a perfect connection with the teachings and souls of religion. The second, it is universal which covers all aspects of the student's personal. The third, paying attention to aspects of balance between spiritual and material. The fourth, related to talents and interests and abilities of students and their social and environmental conditions. The fifth, maintaining the individual differences in students, the surrounding environment and society. The sixth, the principle of development and curriculum change inprogress in order to adapt to social change. The seventh, the connection between subjects, experiences, and activities contained in the curriculum.

Based on the explanation above, there are two processes of integrating Islamic values into learning English, namely: Linking Process, involving two curricula, namely the religious curriculum and the English curriculum into a link where each component still stands alone and has own character. 


\section{Lecture Method}

Efforts to integrate Islamic values in English courses do not only apply to approaches, and educational curricula, but also apply to lecture methods. In addition to developing lecture methods that are often used in English lectures, such as communicative language teaching, collaborative learning, etc., the teachers are also required to apply the method of learning applied in Islamic education. These are the lecture methods applied in Islamic education:

a. Mutual education method

b. Educational methods using instructional methods

c. Educational method by telling stories

d. Guidance and counseling methods

e. Methods of giving examples

f. Discussion method

g. Answering questions Method

h. Methodology (giving parables)

i. Targieb and Tarhieb methods

j. Methods of repentance and forgiveness

k. The method of acquisition (self education), explanation and exposition (instructions)

4. Designing Teaching Materials

Besides the approach and method of lecturing, designing teaching materials that contain Islamic values is very important. When learning English, students and lecturers tend to discuss the values and culture that apply in the west.

\section{Method}

The type of this research was library research (Library Research) which is one type of qualitative research. The fundamental characteristics in this study are that the data studied are written literature in the form of documents or books. This study analyzed the English material taught by the PGMI Program, then integrated it with Islamic values in some material in English subject.

The object of this study focused on the syllabus material in English courses at the PGMI Program and then analyzed the material to be linked or integrated with Islamic values.

The site of this study was carried out in Madrasah Ibtidaiyah Teacher Training Program (PGMI) at the Faculty of Tarbiyah and Teacher Training at UIN North Sumatera. 
To obtain the data needed in this study, the researcher conducted a content analysis. This analysis was intended to conduct an analysis of English materials that would be integrated with Islamic values.

\section{Research result}

1. Islamic Value Integration in English Lectures

In integrating Islamic values in English lectures, there are several aspects that need to be combined, including:

a. Approach

There are several approaches that can be taken, including:

a. Curricular Approach

The Curricular Approach is an approach where the lecturer gives the color of Islam in his learning. This is by putting aside the knowledge of religion with general science. For example, at the State Islamic University; accompanying public faculties and religious faculties.

b. Context-functional approach

The contextual-functional approach is an attempt to answer the question so that all the fields of study presented always wear the views of Islam. But the main stumbling block to realizing this idea lies in the lecturer. Not many lecturers can master general and religious disciplines in a comprehensive manner.

As a lecturer, we are faced with the secular nature applied by western lecturers to the lecture approach in all branches of science. Meanwhile, we believe that Islamic values can be applied through activities and interactions between lecturers and students such as applying basic Islamic values when giving greetings, leaving places, conducting student discussions, reading prayers when starting and closing lessons, etc. where all these activities can also be accompanied by practicing English. For example, usually in greeting, the lecturer said "Good Morning / Afternoon / Evening. How are you today? " We can replace it by saying "Assalamu'alaikum, peace be upon him, and good morning / afternoon / evening, everyone. How are you today? "

Then, if you want to start and end the lesson, students must pray first. Besides that, in class management, we can also emphasize Islamic integrity in gender issues. From an early age, students should be introduced to sit separately between men and women both in working on daily learning assignments and in discussion interactions. By introducing these rules, it is expected that students can understand that Islam has clear rules in terms 
of socializing. Starting from simple things, the application of Islamic values in the context of everyday Muslim life should be better appreciated.

b. Curriculum

The basic foundation of Islamic curriculum preparation must include the following principles: a) Contain basic unitary values for the equality of Islamic values at all time and places; b) contains the value of unity of interest in developing the mission of Islamic teachings; c) contains material which contains spiritual, intellectual and physical development.

The limits of the characteristics of an Islamic curriculum are as follows: 1) The system and curriculum development are in harmony with human nature; 2) directed to achieve the final target for students, namely sincere and obedient worship to Allah; 3) Paying attention to the periodization of student development, typology, nature, and gender; 4) should maintain all the real needs of people's lifewhile still relying on the soul and ideal of Islamic ideals; 5) does not cause conflict in the general sense; 6) can be realized according to the situation and conditions; 7) Flexible so that it can be adapted to various local conditions and situations by keeping in mind the individual civilization factors that concern students' talents, interests and abilities; 8) being effective, conveying and arousing educational value tools that produce positive behavior; 9) paying attention to the development of students (religious feelings and language growth); 10) Paying attention to Islamic religious behavior.

Regarding the principle that became the basic link of the curriculum, al-Syaibani provided the following description; the first, a perfect connection with the teachings and souls of religion. The second, it is universal which covers all aspects of the student's personal. The third, pay attention to aspects of balance between spiritual and material. The fourth, related to talents and interests and abilities of students and their social and environmental conditions. The fifth, maintaining the individual differences in students, the surrounding environment and society. The sixth, the principle of development and curriculum change in progress in order to adapt to social change. The seventh, the connection between subjects, experiences, and activities contained in the curriculum.

Based on the explanation above, there are two processes for integrating Islamic values into English lectures.

a. Linking Process

The linking process involves two curricula, namely the religious curriculum and the English curriculum into a link where each component still stands alone and has its own character. 
The curriculum component includes the profile of graduates, graduate competencies, and the subject matter of the study of the substance of lecture material. The data of lecture process are takencurriculum.

In this study, the first researchers conducted an integration process in the syllabus and then developed it into teaching material. In English lectures there are five skills that need to be mastered, namely: Reading, Speaking, Vocabulary, Writing, and Grammar. In these five sections the integration process is carried out. The following is an integrated English syllabus of Islamic values.

\section{Attached at the end of this report.}

b. Mixing Process

Mixing Process

$\mathrm{A}=$ Islamic Values

$\mathrm{U}=$ English Lecture

$\mathrm{Y}=$ Results of mixing $\mathrm{A}$ and $\mathrm{U}$, substantively and formatively there is no difference between $\mathrm{A}$ and $\mathrm{U}$ in $\mathrm{Y}$
Linking Process

$\mathrm{A}=$ Islamic Values

$\mathrm{U}=$ English Lecture

$\mathrm{X}=$ Results of links $\mathrm{A}$ and $\mathrm{U}$, differ substantively and formatively with A and $\mathrm{U}$

c. Lecturer Method

Efforts to integrate Islamic values in English courses do not only apply to approaches, and curriculum, but also applies to lecture methods. In addition to developing lecture methods that are often used in English learning, such as communicative language teaching, collaborative learning, etc. Lecturers are also required to apply the method of learning applied in Islamic education. These are the lecture methods applied in Islamic education:

1) Mutual education method

2) Learning method byapplying instructional.

3) Storytelling Method

4) Guidance and counseling method

5) Giving examples method

6) Discussion method

7) Answering questions method

8) Methodology (giving parables)

9) Targieb and tarhieb methods

10) Repentance and forgiveness method 
11) Acquisition (self education), explanation and the exposition method.

d. Teaching Material

Efforts to integrate Islamic values in English courses do not only apply to the approach, lecturer curriculum, and lecture methods but also apply to teaching materials. Integrating Islamic values into teaching material is carried out in several ways, including:

a) Adding exercises that reflect Islamic values.

Read the text bellows carefully!

\section{ISLAM AND IMAN}

Islam consists of faith (Iman) and deeds(Amal). Everywhere in the Holy Qur'an you find these two mentioned together. This means that, in the eyes of Allah, faith without good deeds is useless. Similarly, good deeds cannot be fruitful without in the right faith, because faith is away of thinking, and man's action will also actin the wrong way. Therefore, faith means right knowledge, right beliefs, and right thoughts.

There are two kinds of faith, Imani Mujmal (faith in the brief) and Imani Mufassal (faith in detail). This is because power, wealth them rightly, they will be yours if you miss them, they will be taken from you and given to others.

Iman also means belief in the life hereafter, when every man will be shown the record of all he did in life and will betreated according to his deeds. If his good deeds are greater than evil ones, he will enjoy peace and happiness. If not, then he will suffer torture. Iman also requires us to believe in angels who are the servants of Allah and carry out His commands faithfully.

b) Inserting Islamic names for people, places or events into added exercises, for example:

\section{PART 1: NOUNS AND ARTICLE}

\section{Nouns}

Noun is one of the parts of speech in English. The parts of speech are the types of words in English. A noun is a word used to name an object such as people, objects, places, animals, and concepts / ideas. Noun can be singular or plural. 
Example:

\section{People/Noun (stone)}
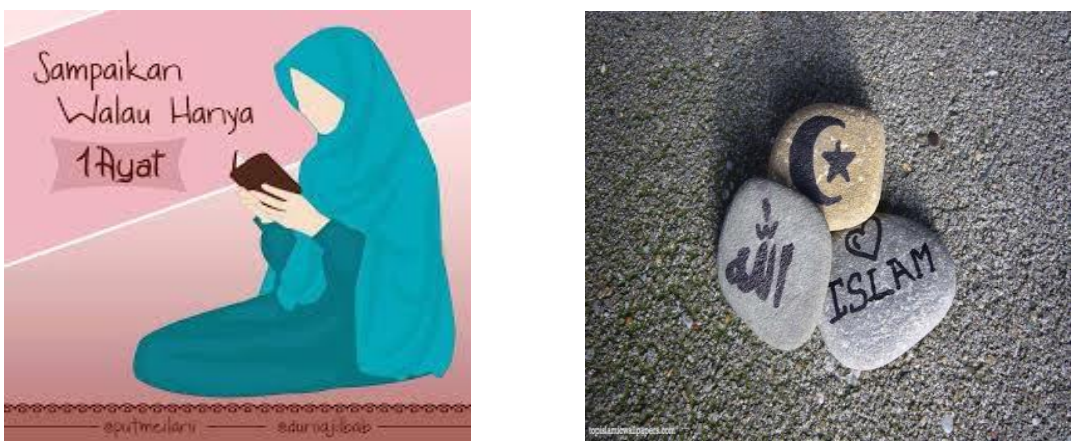

\section{Place $=$ mosque concept $/$ idea}
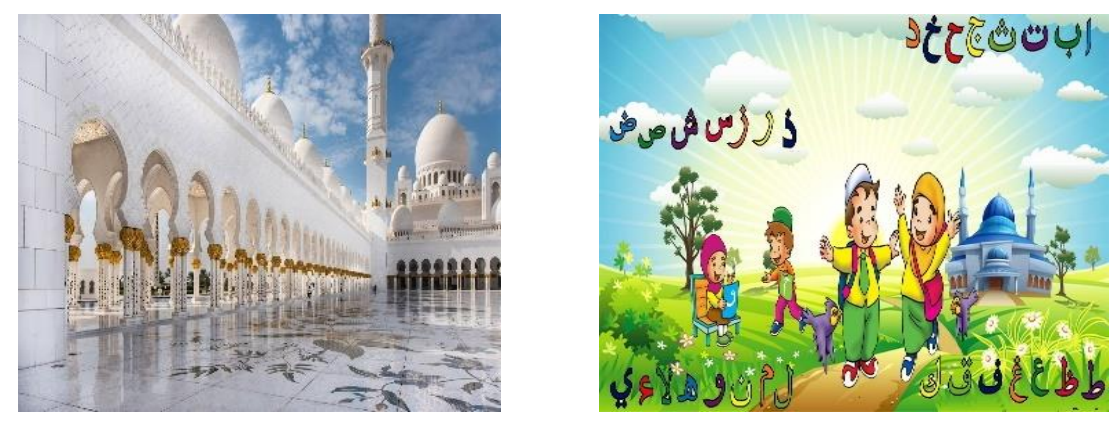

\section{Animals}

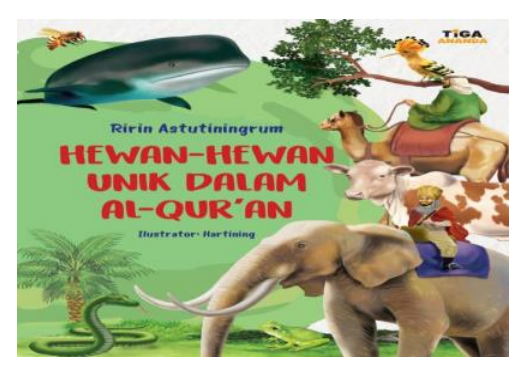

Example:

Aisyah always read a holy Qur'an in my room.

\section{Note:}

Ayesha: Name of person

Mosque: Place

The war of Badr: War of Badr

The above example explains that in the process of integration in teaching materials, we can do this by using Islamic names, for example: Aisyah that usually uses the names of strangers such as John, the name of a place for worship such as a mosque which usually uses the word church, for example in the text below: 
"Church is a place for Christian people praise to God. Church is for us to communicate with other Christian people and communicate with Jesus. All Christian people should go there to praise Lord and they would get a blessed from God".

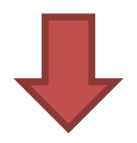

It can be changed to be

"Istiqlal Mosque is the largest mosque in Southeast Asia. This mosque is a pride for the nation of Indonesia, as a manifestation of an expression of gratitude to Allah SWT for the outpouring of His grace, the nation's Muslim -majority Indonesia can successfully fight for independence and the formation of the State of RI. Hence it is called Istiqlal mosque means FREEDOM.

c) Using English texts about history or stories of the Prophets, for example:

\section{PROPHET MUHAMMAD SAW}

Muhammad was born in Mecca ( Makkah), Arabia, on Monday, 12 Rabi' Al-Awal (2 August A.D. 570). His mother, Aminah, was the daughter of Wahb Ibn Abdu Manaf of the Zahrah family. His father, 'Abdullah, was the son of Abdul Muttalib. His genealogy has been traced to the noble house of Ishmael, the son of Prophet Abraham in about the fortieth descend. Muhammad's father died before his birth.

Before he was six years old his mother died, and the doubly orphaned Muhammad was put under the charge of his grandfather Abdul Muttalib who took the most tender care of him. But the old chief died two years afterwards. On his deathbed he confided to his son Abu Talib the charge of the little orphan.

When Muhammad was twelve years old, he accompanied his uncle Abu Talib on a mercantile journey to Syria, and they proceeded as far as Busra. The journey lasted for some months. It was at Busra that the Christian monk Bahira met Muhammad. He is related to have said to Abu Talib: 'Return with this boy and guard him against the hatred of the Jews, for a great career awaits your nephew."

After this journey, the youth of Muhammad seems to have been passed uneventfully, but all authorities agree in ascribing to him such correctness of manners and purity of morals as were rare among the people of Mecca. The fair character and the honorable bearing of the unobtrusive youth won the approbation of the citizens of Mecca, and by common consent he received the title of "Al Ameen," The Faithful. 
Through this text, students know clearly the Prophet's curriculum vitae, with the rapid development of technology and science, students are worried not to know the history of life of the Prophet at all.

It is also hoped that with this text will strengthen his love for his Prophet, the great Prophet Muhammad SAW.

d) Mixing expressions - typical Islamic expressions with English language expressions that are in accordance with the main material of learning, for example:

a) Using Islamic textual image media that can be used by lecturers to assess the ability of students to write words, paragraphs, to perfect texts, for example:

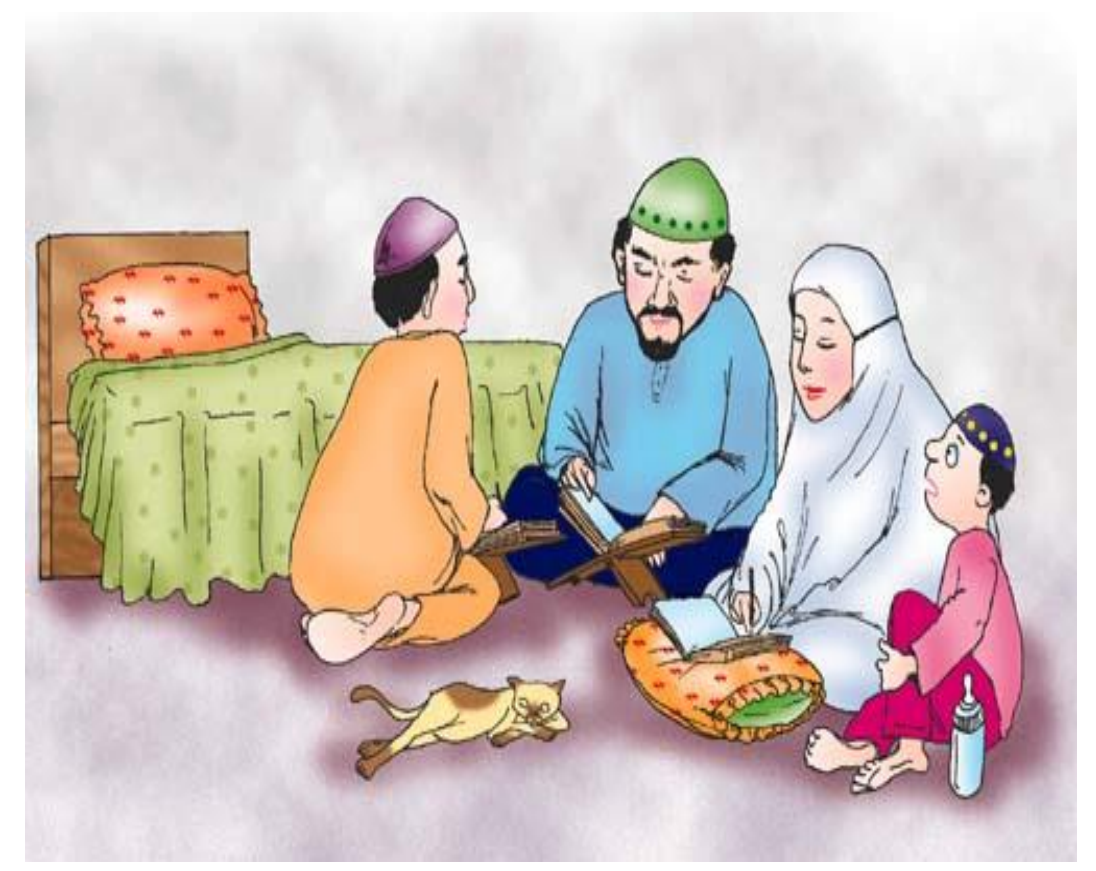

From this text, students can be directed to write a short story that contains the picturemedia which have been provided. This can help students improve their skills in grammar and writing and also students will be familiar with Islamic picture media.

\section{Conclusion}

From the results of the study it could be concluded that: In integrating Islamic values in lectures, there were several aspects that need to be combined, including: (1) approach; (2) curriculum; (3) teaching material; and (4) lecture methods.

Integrating Islamic values into lecture material is carried out in several ways, including: (1) adding exercises that reflect Islamic values into the topic being taught; (2) inserting Islamic names for people, places or events into exercises; (3) using English texts about history or stories of the Prophets; and (4) using Islamic expressions that are in accordance with the lecture material; (5) Using Islamic picture media. 


\section{References}

Amelia Riza, (2012). Merancang Perkuliahan Bahasa Inggris BerbasisPendekatan Islami: Jurnal Pemikiran Islam; Vol.37(1).

Ayatusa'adah, Nanik Lestariningsih, dan Yatin Mulyono, (2017). Integrasi NilaiNilai Keislaman Dalam Kurikulum Dan Perkuliahan Program Studi Tadris Biologi: Jurnal Pendidikan Sains \& Matematika, Vol.5(2).

M.AminAbdullah, (2018) Multidisiplin, Interdisiplin, Transdisiplin Ilmu Pengetahuan dan Riset pada Pendidikan Tinggi Masa Depan, (Bahan Rapat Kerja UINSU Medan): Hotel Inna Parapat, Danau Toba.

http://eprints.uny.ac.id/482/1/strategiintegrasi.pdf. visited 29 Agustus 2018 Hasan Langgulung, (1987) Azas-Azas Pendidikan Islam, Jakarta: Pustaka al-Husna. Imam Suprayogo, (2005) Membangun Integrasi Ilmu dan Agama: Pengalaman UIN Malang, dalam Integraasi Ilmu dan Agama: Interpreasi dan Aksi, editor Zainal AbidinBagir dkk, yogyakarta: SUKA Press2005.

Ismail Raji Al-Faruqi, (2003) Islamisasi Ilmu Pengetahuan, Bandung : Pustaka, h. 9 Kuntowijoyo, (2006) Islam Sebagai Ilmu, Epistemologi, Metodologi, dan Etika,Yogyakarta: Tiara Wacana.

Khamdan,N.,(2002), Integrasi Perkuliahan Bahasa Inggris dengan Nilai- $\quad$ nilai islami di SMP Islam Al-Azhar15 Cilacap,

Mulyadhi Kartanegara, (2005) Integrasi Ilmu, Sebuah Rekonstruksi Holistik, Bandung: Arasy: PT Mizan Pustaka.

M.Isa QudwatinNisak, (2014). Pengintegrasian Nilai Islami Dalam Pelaksanaan

Simulasi Perkuliahan Bahasa Inggris, UIN Ar-Raniry:Conference Proceedings -ARICISI.

Pratama, Melgis Dilkawaty, (2013). Integrasi Nilai-Nilai Islam Dalam Perkuliahan Bahasa Inggris: Jurnal UIN Sultan Syarif Kasim Riau.

Sauri, S (tt). (2007) Integrasi Imtak dan Imptek Dalam Pembelajaran. Makalah: Tidak diterbitkan.

Suwarna.(2007). Strategi Integrasi Pendidikan Budi Pekerti dalam Pembelajaran. Yusuf Al-Qardhawi, Jakarta: Bulan Bintang.

Suprayogo, Imam, (2012). Implementasi konsep integrasi Ilmu dan Agama, http://old.uin.malang.ac.id/index.php?option=com_conten\&view $=$ article\&id=974:isI am-dan-masyarakat-unggul\&catid=25:artikel-imam-suprayogo, 2011, visited 27-o82018, pukul 22.15 wib. 